\title{
Inflammation and Atherosclerosis: Current Pathogenesis
}

\author{
Anna Meiliana ${ }^{1,2 *}$ and Andi Wijaya $a^{1,2}$ \\ ${ }^{1}$ Post Graduate Program in Clinical Biochemistry, Hasanuddin University, Jl. Perintis Kemerdekaan Km.10. Makassar, Indonesia \\ ${ }^{2}$ Prodia Clinical Laboratory, Jl. Cisangkuy No.2, Bandung, Indonesia \\ ${ }^{*}$ Correspondence: Prodia Clinical Laboratory, Jl. Cisangkuy No.2, Bandung, Indonesia \\ e-mail: anna_m@prodia.co.id
}

\section{Abstract}

B ACKGROUND: The inflammatory nature of atherosclerosis is well established but the agent(s) that incite inflammation in the artery wall remain largely unknown.

CONTENT: Chronic inflammation is recognized as a major driving force in atherogenesis. The sites of atherosclerotic plaque development in the arterial wall are characterized by cholesterol accumulation and infiltration of peripheral blood monocytes, which gradually differentiate into macrophages. Cholesterol crystals, the common constituents of atherosclerotic lesions, induce NLRP3 inflammasome activation and IL $-1 \beta$ secretion in human macrophages, promote an inflammatory milieu and thus drive lesion progression. Consequently, the cholesterol crystal-induced inflammasome activation may represent an important link between cholesterol metabolism and inflammation in atherosclerotic lesions.

SUMMARY: The crystalline cholesterol acts as an endogenous danger signal and its deposition in arteries or elsewhere is an early cause rather than a late consequence of inflammation. The cholesterol crystalinduced inflammasome activation in macrophages may represent an important link between cholesterol metabolism and inflammation in atherosclerotic lesions. This finding provides new insights into the pathogenesis

\section{Abstrak}

ATAR BELAKANG: Proses Inflamasi pada aterosklerosis merupakan hal yang sudah terbukti, tetapi pemicu terjadinya inflamasi pada dinding arteri masih belum jelas.

ISI: Inflamasi kronik merupakan faktor pemicu aterogenesis. Pembentukan plak pada dinding arteri ditandai dengan adanya akumulasi kolesterol dan infiltrasi monosit darah perifer, yang selanjutnya akan berdiferensiasi menjadi makrofag. Kristal kolesterol, unsur yang paling banyak ditemukan pada lesi aterosklerosis, dapat menginduksi aktivasi inflamasom NLRP3 dan sekresi IL-1 $\beta$ pada makrofag. Hal ini dapat memicu terjadinya inflamasi sehingga memperburuk lesi. Jadi, aktivasi inflamasom oleh kristal kolesterol dapat dikatakan sebagai penghubung antara metabolism kolesterol dan inflamasi pada lesi aterosklerosis.

RINGKASAN: Kristal kolesterol dapat berperan sebagai signal berbahaya endoge, dan penumpukan Kristal kolesterol pada dinding arteri atau dimanapun merupakan penyebab awal, bukan konsekuensi akhir inflamasi. Aktivasi inflamasom pada makrofag oleh kristal kolesterol merupakan penghubung antara metabolisme kolesterol dan inflamasi pada lesi aterosklerosis. Penemuan ini merupakan paradigma baru tentang pathogenesis 
of atherosclerosis and indicates new potential molecular targets for the therapy of this disease.

KEYWORDS: Atherosclerosis, inflammation, neutrophil, macrophages, inflammasome, cholesterol crystal

Indones Biomed J 2012; 4 (2): 73-83 aterosklerosis dan memberi ide baru untuk pengembangan target terapi molekuler pada aterosklerosis.

KATA KUNCI: Aterosklerosis, inflamasi, neutrophil, makrofag, inflamasom, kristal kolesterol

Indones Biomed J 2012; 4 (2): 73-83

\section{Introduction}

Atherosclerosis is a chronic disease of the arterial wall and a leading cause of death and loss of productive lives worldwide. Research into the disease has led to many compelling hypotheses about the pathophysiology of atherosclerotic lesion formation and of complications such as myocardial infarction and stroke. Despite these advances, however, we still lack definitive evidence to show that processes such as lipoprotein oxidation, inflammation and immunity have a crucial involvement in human atherosclerosis (1).

The underlying pathogenesis involves an imbalanced lipid metabolism and a maladaptive immune response entailing a chronic inflammation of the arterial wall. The disturbed equilibrium of lipid accumulation, immune responses and their clearance is shaped by leukocyte trafficking and homeostasis governed by chemokines and their receptors. New pro and anti-inflammatory pathways linking lipid and inflammation biology have been discovered, and genetic profiling studies have unveiled variations involved in human CAD. The growing understanding of the inflammatory processes and mediators has uncovered an intriguing diversity of targetable mechanisms that can be exploited to complement lipid-lowering therapies (2).

Lipids have a central role in the pathogenesis of plaques, but the mechanistic links between lipids and atherogenesis remain unclear. Observational data support a strong association between plasma lipid concentration and the risk of cardiovascular disease (3). LDL concentration correlate with the risk of cardiovascular events in human populations and augment individual susceptibility to atherosclerosis and its complications. Several interventions to lower LDL concentration by independent mechanisms diminish the likelihood of atherosclerotic events.

But, even in patients treated with statins a considerable residual burden of cardiovascular risk remains (4). More than $20 \%$ of patients have a recurrent event within 30 months after acute coronary syndrome, despite a highdose statin treatment (5).

Consistent evidence has shown that concentrations of high-density lipoprotein (HDL) correlate inversely with cardiovascular risk. Numerous methods of approach to increase HDL already exist or are still in development. Because of the heterogeneity in HDL particles, the complicated pathways of cholesterol flux mediated by HDL and the association of HDL with many proteins that may modify atherosclerosis, the steady-state concentrations of HDL cholesterol in the blood reflect HDL function poorly. HDL not only can mediate reverse cholesterol transport, but it can also exert anti-inflammatory actions both in vitro and in vivo (6). HDL particles associate with dozens of proteins, many of which have biological activities relevant to atherogenesis (7).

A unifying view of the pathophysiology of atherosclerosis has proposed that inflammation has a key role in or transduces the effects of many known risk factors for the disease $(8,9)$. Inflammatory signaling alters the behavior of the intrinsic cells of the artery wall (endothelium and smooth muscle) and recruits further inflammatory cells that interact to promote lesion formation and complications.

The application of biomarkers of inflammatory status such as C-reactive protein (CRP) has lent clinical credence to this concept, but not without controversy. The association of inflammatory biomarkers with future risk of atherosclerotic complications does not demonstrate causality. Although both experimental and clinical evidence may have convinced some workers, the intriguing question about which comes first and which comes next regarding the causality, remains unresolved.

Polymorphonuclear leukocytes (neutrophils) have been detected in aortic fatty-streak lesions of primates and have been correlated with CAD incidence and severity (10). Notably, hyperlipidemia triggers neutrophilia by stimulating granulopoiesis and bone marrow egress, which involves elevated CXCL1 plasma concentrations, 
while the number of circulating neutrophils correlates closely with the plaque size (11).

Foam cell formation involves phagocytosis of matrix-retained lipoproteins and fluid-phase pinocytosis of aggregated lipoproteins by macrophages (12), but substantial evidence also suggests that oxidative modification of subendothelially accumulated LDL triggers the inflammatory process underlying atherosclerosis.

An intriguing finding is the presence of small cholesterol crystals in human and mouse atherosclerotic lesions. The crystals appear simultaneously with lesion macrophages and accumulate in subendothelial and necrotic areas and promote atherogenesis by activating the NLRP3 inflammasome, a Pattern Recognition Receptor (PRR) platform mediating IL-1 $\beta$ secretion (via caspase-1) and neutrophil recruitment $(13,14)$. Thus, the interference with cholesterol crystal formation or inflammasome activation may become an effective therapeutic strategy for preventing atherogenesis under defined conditions.

\section{Inflammation in Atherosclerosis}

The term inflammation comes from the Latin word inflammare, which means to set on fire, acknowledging one of the four cardinal signs of inflammation first recognized by Celsus almost 2000 years ago (15), which has been memorized by many generations of medical students ever since. Much has changed since these early observations, yet the important themes persist. We now recognize inflammation as a set of interrelated processes and intersecting mechanistic pathways rather than solely a constellation of signs and symptoms (16). In recent years, researches have unraveled a remarkable and complex series of molecular mechanisms constituting the inflammatory response.

Our understanding of atherosclerosis has progressed remarkably over the past few years. The discovery of subsets of inflammatory and resident monocytes, M1 and M2 macrophages, NKT cells, and Tregs opened new perspectives on the role of inflammation and immune responses in atherosclerosis. New data suggest an important role of chemokine and chemokine receptors in atherosclerosis and highlight a network of cytokines that modulate the immune response and inflammation in the aortic wall. All phases of atherosclerosis are regulated by inflammatory mechanisms that provide overlapping networks of pathways involved in the regulation of immune cell functions, activation of endothelium, and alteration of metabolic parameters. Increasing evidence suggests that components of the immune system may alter lipid metabolism and thus affect atherosclerosis in yet another way (17).

Atherosclerosis is an inflammatory disease with a strong involvement of innate immunity. It relies on a set of PRRs for detection and clearance of harmful material and included among these are Toll-like receptors (TLRs) and cytoplasmic Nucleotide-binding oligomerization domain (NOD)-like receptors (NLRs). These groups of receptor recognize diverse molecular structures called pathogenassociated molecular patterns (PAMPs), ranging from lipids and proteins to nucleic acids that are common to many microorganisms (18).

Tissue damage can also trigger a process of sterile inflammation, which was originally proposed by Matzinger (19) almost two decades ago. Her 'danger model' indicates that endogenous damage-associated molecular patterns (DAMPs) created during tissue injury can alert our body defence toward impending dangers by activating PRRs in the absence of pathogens. Some DAMPs are intracellular molecules that are released into the extracellular milieu as a result of necrosis and become danger signals that activate immune cells and vascular endothelium. In the context of atherosclerosis, a growing body of evidence infers modified LDL as the primary DAMP (20).

It is clear that oxidation-modified LDL induces inflammatory responses via activation of TLRs, but which exact ligand drives the response and which specific signaling mechanisms play role in the process, are yet to be identified. NLR inflammasome-mediated innate immune signaling may have a key role in the development of atherosclerosis.

Studies of LDL-derived bioactive components have shown phospholipids and cholesterol crystals as danger signals that trigger oxidative stress, inflammatory responses via activation of TLR, and NLRP3 inflammasome pathways, respectively. However, LDL particles may also yield additional protein-based DAMPs rather than the defined lipid derivatives, given the observation that atherosclerosis develops strong antibody responses against certain ApoB fragments (21). These recent findings provide new avenues for understanding of the etiology and therapy of atherosclerosis, which is currently a global pandemic.

Together, these findings establish a broad implication of inflammasome in the pathogenesis of cardiovascular diseases. It is interesting to question whether NLRP3 inflammasome and IL- $1 \beta$ signaling can be translated as targets of therapy for atherosclerosis. 


\section{Neutrophils in Atherosclerosis}

The paradigm of atherosclerosis as a chronic inflammatory condition gained further traction as chemokines responsible for monocyte and lymphocyte trafficking were found to regulate atherosclerosis (8). In addition, tantalizing indirect evidence has also emerged about implication of neutrophils in the initiation, progression, and complications of atherosclerosis (22).

Atherosclerosis is a chronic inflammation of the arterial vessel wall with relatively well-defined roles of leukocytes such as macrophages and lymphocytes. Recent studies, however, have shown that neutrophils infiltrate atherosclerotic lesions at various time points $(2,11,23-25)$ and depletion studies provide evidence for a proatherogenic role of neutrophils $(11,26)$. Much of the neutrophil-dependent proinflammatory activity can be attributed to the release of preformed granule proteins, which are discharged into the surroundings of activated neutrophils (27-29).

Neutrophils contain granules with more than 300 different proteins that undergo limited exocytosis on neutrophil extravasation (30). Some of these proteins are able to activate and recruit immune cells and thus have been coined alarmins (31). Cathelicidins (CRAMP in mouse, LL37 in humans) residing in neutrophil secondary granules were shown to potently activate and recruit monocytes and macrophages $(32,33)$, thus fulfilling alarmin criteria. Expression of granule proteins such as azurocidin, LL-37, $\alpha$-defensins, and NGAL is largely restricted to neutrophils (28). Interestingly, all of these granule proteins were identified by immunohistochemistry in human atherosclerotic lesions (34-37), suggesting that these proteins might be footprints of neutrophils.

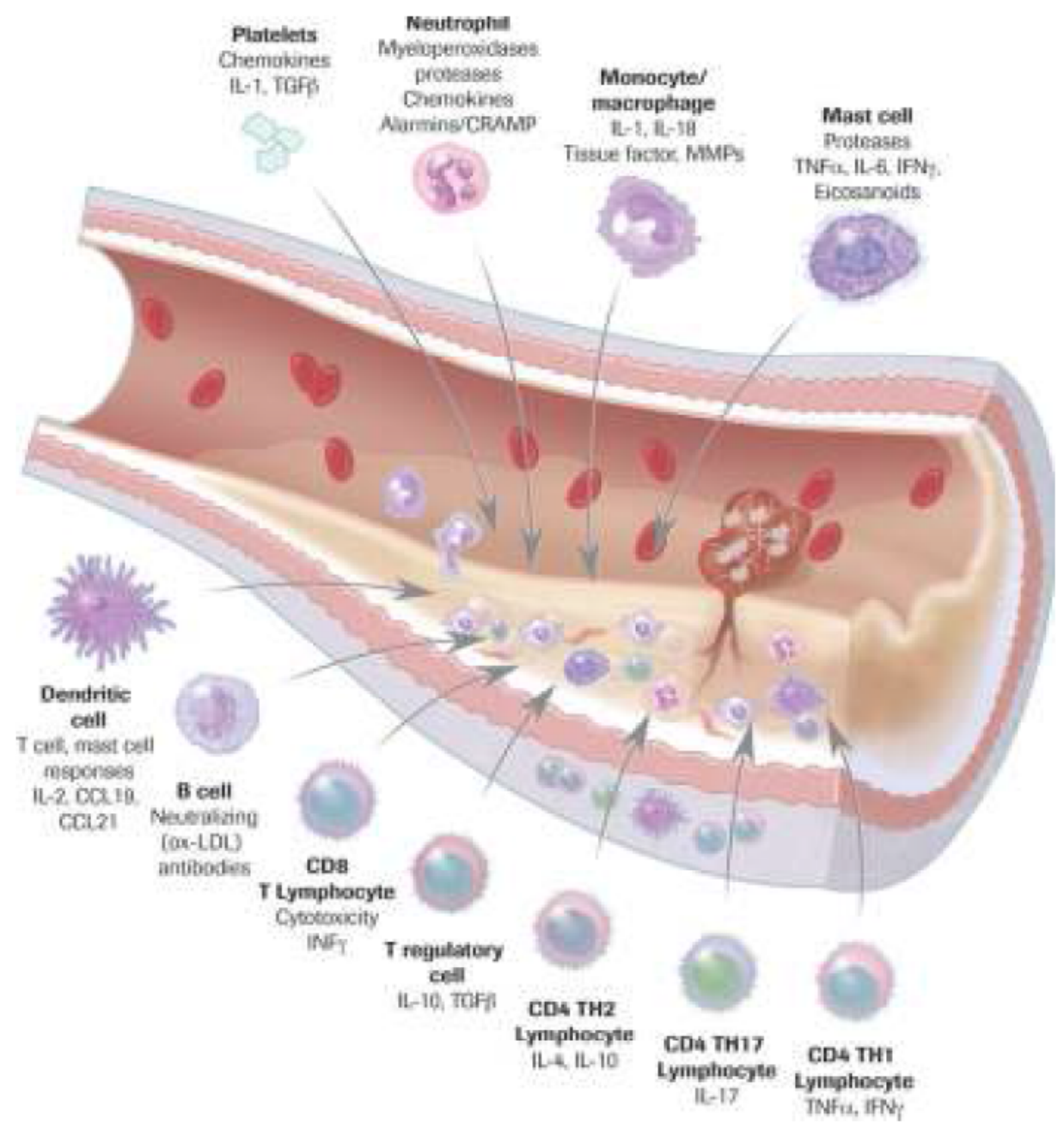

Figure 1. The inflammatory basis of atherosclerosis (adapted with permission from Simon DI et al, American Heart Association Inc. 2012). 
Azurocidin stimulates endothelial protein kinase C (38), which may explain the enhanced expression of vascular cell adhesion molecule-1 and the intercellular adhesion molecule-1 and subsequent adhesion of human monocytes (39). Similarly, proteinase-3 induces expression of these 2 cell adhesion molecules resulting in enhanced adhesion of neutrophils and monocytes to isolated endothelial cells (40). Proteinase-3 also stimulates endothelial expression of CCL-2 (40), thus providing an alternative mechanism of stimulating monocyte recruitment. Similarly, neutrophil-derived $\alpha$-defensins also enhance chemokine and cell adhesion molecule expression (41). Furthermore, $\alpha$-defensins aggravate endothelial dysfunction by increased radical production and reduction in nitric oxide availability (42). Besides granule proteins, neutrophil-derived cytokines were also recently found to enhance expression of cell adhesion molecules and, consequently, promote adhesion of monocytes (43).

Recent data from mouse models of atherosclerosis indicate that neutrophils accumulate in large arteries soon after the beginning of high-fat diet feeding $(11,26,44)$. Lesion sizes correlate positively with circulating neutrophils counts, and depletion of neutrophils with subsequent reduction in lesion sizes provide conclusive evidence for the role of neutrophils at the early time points of atherosclerosis (11).

In addition, alterations in neutrophil phenotype and homeostasis in response to primary risk factors of atherosclerosis in humans paralleling observations on mouse models (45) suggest that neutrophils may also play important role in the early phases of human atherosclerosis.

Granule proteins, however, not only are localized in atherosclerotic lesions, but also secreted into the plasma in neutrophil activation. Hence, several proteins typically expressed and released by neutrophils have emerged as possible biomarkers. MPO, for example, is abundantly expressed in neutrophil primary granules and partially released in neutrophil activation. Through its catalytic activity, MPO contributes to radical formation and subsequently promotes formation of oxidized low-density lipoprotein (46).

Similarly, MMP-2 and MMP-9, which are abundant in neutrophil secondary and tertiary granules, were found to be elevated in patients with acute coronary syndrome (47). Because neutrophils contain large amount of matrixdegrading proteases, produce vast amounts of oxygen species, and rapidly undergo apoptosis, it is very likely that neutrophils promote plaque rupture or erosion (48).

Results of recent studies have suggested the existence of neutrophil activation during atherosclerosis and continuous recruitment of neutrophils at various stages of atherosclerosis; therefore laying the basis for investigating the mechanisms by which neutrophils contribute to the formation of atherosclerotic lesions (24).

\section{Macrophages in Atherosclerosis}

Monocytes, macrophages, and dendritic cells are key cells in the initiation and progression of atherosclerosis. Vascular inflammation is associated with and, in a large part driven by, changes in the leukocyte compartment of the vessel wall. Although the arterial wall contains a large number of resident macrophages and some resident dendritic cells, atherosclerosis drives a rapid influx of inflammatory monocytes $\left(\mathrm{Ly}-6 \mathrm{C}^{+}\right.$in mice) and other monocytes $\left(\mathrm{Ly}-6 \mathrm{C}^{+}\right.$in mice, also known as patrolling monocytes). Once present in the vessel wall, Ly-6C+ monocytes differentiate to a phenotype consistent with inflammatory macrophages and inflammatory dendritic cells (49). The phenotype of these cells is modulated by lipid uptake, Toll-like receptor ligands, hematopoietic growth factors, cytokines, and chemokines. In addition to the newly recruited macrophages, it is likely that resident macrophages also change their phenotype. Monocytederived inflammatory macrophages have a short half-life. After undergoing apoptosis, they may be taken up by surrounding macrophages or, if the phagocytic capacity is overwhelmed, can undergo secondary necrosis, a key event in forming the necrotic core of atherosclerotic lesions (50).

The key early inflammatory response to retained apoBLPs, which may be enhanced by oxidative modification of the LPs, is activation of overlying endothelial cells in a manner that leads to recruitment of blood-borne monocytes $(51,52)$. Activated endothelial cells secrete chemoattractants, or "chemokines," that interact with cognate chemokine receptors on monocytes and promote directional migration.

Driven by macrophage colony-stimulating factor (M-CSF) and probably by other differentiation factors, the majority of monocytes in early atherosclerotic lesions become cells with macrophage- and/or dendritic celllike features $(53,54)$. There has been great interest in macrophage heterogeneity in atherosclerotic lesions, particularly regarding macrophages involved in proinflammatory processes (M1) versus those involved in resolution and repair (M2). 
Diversity and plasticity are hallmarks of the monocyte - macrophage system (54-60), which are reflected in plaque formation and evolution. Different monocyte subsets, which differentially contribute to plaque infiltration and to atherosclerosis complications, have been identified. Similarly, depending on different environmental signals plaque-associated macrophages can express polarized pro- and antiatherogenic programs by influencing lipid metabolism, inflammatory responses, and plaque stability. Thus, a "macrophage balance" plays a major role in the pathogenesis of atherosclerotic plaques and affects evolution and complications of atherosclerosis (61).

Even at the very early stages of atherogenesis, many macrophages and dendritic-like cells have membranebound lipid droplets in the cytoplasm. These lipid-loaded cells are called "foam cells," and their formation begins when phagocytes ingest and process apoB-LPs. Early work suggested that uptake of oxidized LDL occurs via scavenger receptors, notably the type A scavenger receptor (SRA) and a member of the type B family, CD36 (62). However, recent gene-targeting studies in apolipoprotein E (ApoE-deficient mice), indicate that additional mechanisms of foam cell formation are also operational in atherosclerosis $(63,64)$. In vitro work suggests plausible mechanisms including phagocytosis of matrix-retained and aggregated LPs and fluid phase pinocytosis of nonretained native LDL $(65,66)$.

Once ingested, the cholesteryl esters of the LPs are hydrolyzed in late endosomes to cholesterol, often referred to as free cholesterol, and fatty acids $(67,68)$. Late endosomal free cholesterol is trafficked to peripheral cellular sites by poorly understood mechanisms involving the late endosomal proteins NPC1 and NPC2 and the lipid lysobisphosphatidic acid. Recent work also points to a possible role of the $\mathrm{ABC}$ transporter protein $\mathrm{ABCG} 1$ in

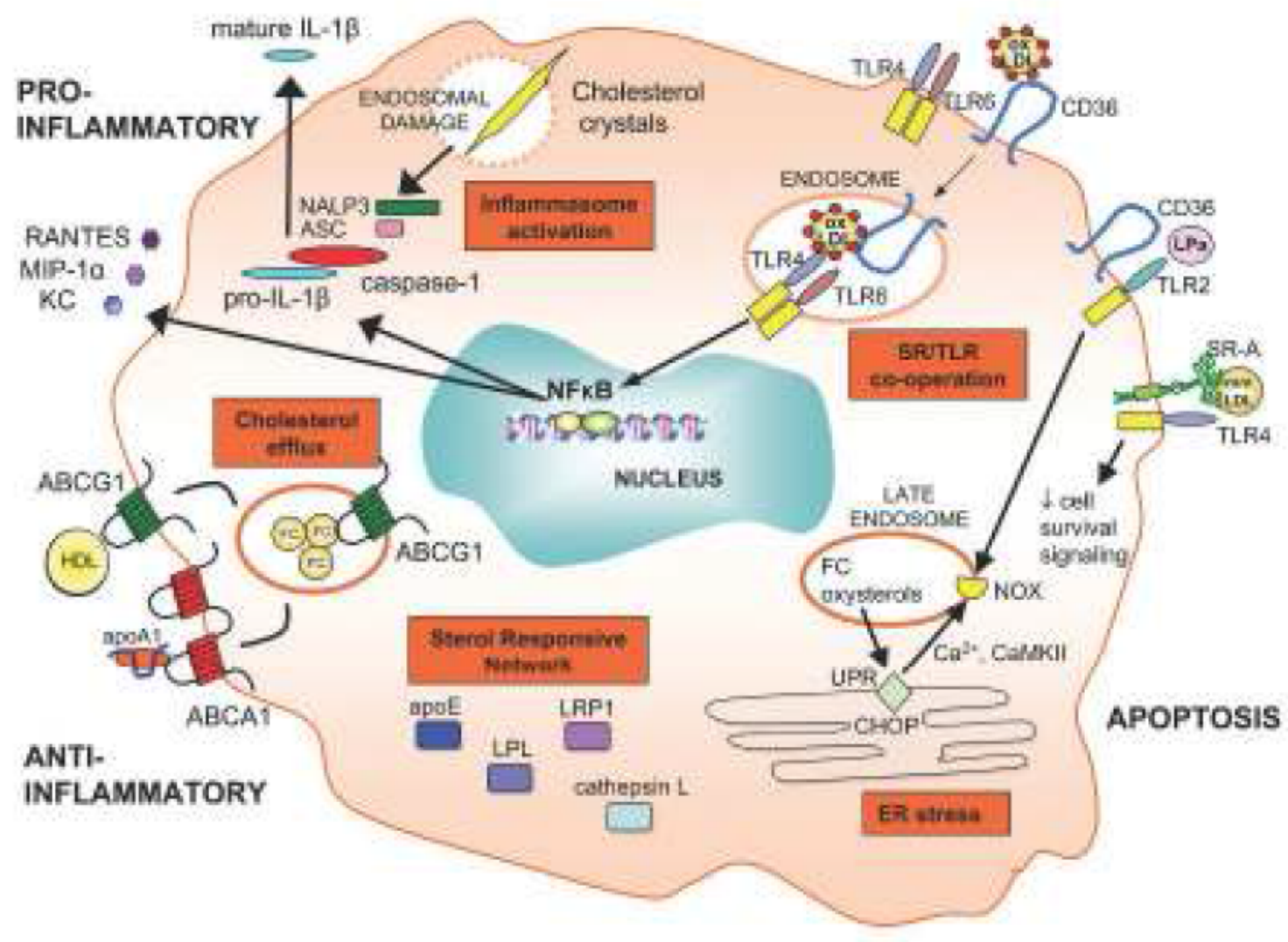

Figure 2. Signaling pathways in macrophages of atherosclerotic lesions (adapted with permission from Moore KJ et al, Cell Press 2011). 
this process (68). Free cholesterol released from lysosomes and from rehydrolyzed cholesteryl ester droplets can also traffic to the plasma membrane and thus be available for efflux out of the cell $(69,70)$. Cholesterol efflux is thought to be a major process involved in plaque regression when hypercholesterolemia is reversed.

A key component of the chronic inflammation characteristics of the atherosclerotic plaque is a persistent influx of mononuclear phagocytes, which are the major leukocyte population present in atherosclerotic lesions $(71,72)$. Here they ingest lipoprotein particles and give rise to foam cells and contribute to atherogenic process by regulating lipid metabolism and orchestrating inflammatory responses $(17,73)$. In particular, they contribute to evolution of the plaque by secreting cytokines and reactive oxygen species, and play a major role in weakening and destabilization of the fibrous cap by releasing proteases $(71)$.

A fascinating new area is the role of macrophage inflammasome signaling in atherosclerosis (Figure 2). When macrophages are exposed to crystalline material, IL$1 \beta$ and IL-18 protein maturation and secretion are effected through an inflammasome complex involving multiple proteins, notably NLRP3, ASC, and caspase-1 $(13,14)$. Cholesterol crystals have been shown to exist even in early atherosclerotic lesions. Cholesterol crystal-induced macrophage inflammation involves phagolysosomal disruption, inflammasome components, and the lysosomal proteases cathepsin B and cathepsin L $(13,14)$.

Macrophages alter their phenotype and biological function in response to plaque lipids through the upregulation of specific sets of genes. Interaction of oxidized lipids with pattern recognition receptors and activation of the inflammasome by cholesterol crystals drive macrophages toward an inflammatory M1 phenotype. A new phenotype, Mox, develops when oxidized phospholipids activate stress response genes via Nrf2. Other lipid mediators such as nitrosylated-fatty acids and omega-3 fatty acid-derived products polarize plaque macrophages toward anti-inflammatory and proresolving phenotypes (74). Subpopulations of proinflammatory and anti-inflammatory macrophages were identified in human lesions $(75,76)$ and in advanced atherosclerotic lesions of low density lipoprotein receptor (LDL-R) null mice, where the relative abundance of macrophage phenotypes was found to be $40 \%$ M1, 30\% Mox, and 20\% M2 (77).

In summary, there is substantial evidence that plaque pathogenesis and evolution are influenced by macrophage activation and polarization, and M1- and M2like macrophages coexisting in human atheromas (76). Plaque-associated macrophages can express diverse pro- and antiatherogenic functions, and the balance of these different activation profiles influences atheroma evolution and outcome.

\section{Endoplasmic Reticulum in Atherosclerosis}

In recent years, considerable evidence has shown that inflammation within the cardiovascular system is linked to endoplasmic reticulum (ER) stress and unfolded protein response (UPR), which alters gene expression and translational programs to overcome stressful conditions and restore ER homeostasis (78-81). Recent evidence suggests that ER stress is a key factor in inflammatory response and a potential mediator of inflammation in cardiovascular disease (82-84).

Prolonged activation of the ER stress pathway known as the UPR can lead to cell pathology and subsequent tissue dysfunction. There is now ample evidence that the UPR is chronically activated in atherosclerotic lesional cells, particularly advanced lesional macrophages and endothelial cells. The stressors in advanced lesions that can lead to prolonged activation of the UPR include oxidative stress, oxysterols, and high concentrations of intracellular cholesterol and saturated fatty acids (85). In the macrophages, prolonged ER stress triggers apoptosis, which in turn leads to plaque necrosis if the apoptotic cells are not rapidly cleared. ER stress-induced endothelial cell apoptosis may also contribute to plaque progression. Another potentially important proatherogenic effect of prolonged ER stress is activation of inflammatory pathways in macrophages and, perhaps in response to atheroprone shear stress, endothelial cells (85).

In advanced lesions, ER stress is prominent in macrophages and can lead to inflammation and apoptosis in these cells. When apoptotic macrophages are not rapidly cleared by neighboring phagocytes, they become secondarily necrotic and lead to the generation of necrotic core, a key feature of clinically dangerous plaques. ER stress in advanced lesions may also cause the death of ECs, which may further amplify plaque progression and disruption, and cell death of smooth muscle cells, which may contribute to thinning of the protective fibrous cap (85).

Inflammatory pathways and ER stress are integrated also through the intracellular calcium and the generation of ROS $(79,83)$ Nitric oxide (NO) synthesized by inducible NO synthase (iNOS) in inflammatory cells can 
activate ER stress signaling pathways through disturbance of $\mathrm{ER} \mathrm{Ca}^{2+}$ homeostasis, or enhancing ROS generation, or inhibiting protein disulfide isomerase (PDI) by NOinduced S-nitrosylation (84). Thus, ER stress is an important component of chronic inflammation, which plays a critical role in the development of atherosclerosis.

\section{NLRP3 Inflammasomes}

The innate immune system relies on its capacity to rapidly detect invading pathogenic microbes as foreign and to eliminate them. The discovery of Toll-like receptors (TLRs) provided a class of membrane receptors that sense extracellular microbes and trigger antipathogen signaling cascades. More recently, intracellular microbial sensors have been identified, including NOD-like receptors (NLRs). Some of the NLRs also sense nonmicrobial danger signals and form large cytoplasmic complexes called inflammasomes that link the sensing of microbial products and metabolic stress to the proteolytic activation of the proinflammatory cytokines IL-1 $\beta$ and IL-18 (86).

Matzinger $(87,88)$ has suggested that the activation of the innate immune system is not only based on the recognition of PAMPs, but it also relies on the presence of danger signals or danger-associated molecular patterns (DAMPs) released by injured cells. These two models seem to be completely opposed, but several recent reports have shown activation of innate immunity by the host molecules. Mammalian dsDNA $(89,90)$ and uric acid crystals (89), among others, activate an inflammatory response.

Inflammasomes are a group of protein complexes that recognize a diverse set of inflammation-inducing stimuli including PAMPs and DAMPs, and control the production of important pro-inflammatory cytokines such as IL-1 $\beta$ and IL-18 $(91,92)$. Furthermore, they have the ability to regulate other important aspects of inflammation and tissue repair such as pyroptosis, a form of cell death. IL$1 \beta$ is one of the quintessential pro-inflammatory cytokines that broadly affects inflammatory processes (93). Tight control of its production is therefore required at the transcriptional and post- translational concentrations. IL-1 $\beta$ is synthesized as a pro-protein without a typical signal sequence that would allow its secretion, and instead its activation and cellular release are controlled by cysteine protease caspase-1 (94). Similarly, caspase-1 is responsible for processing and secretion of IL-1 (95) as well as the secretion of other proteins such as IL-1 $\alpha$ and fibroblast growth factor-2 through an unconventional protein secretion pathway (95). Moreover, caspase-1 is required for pyroptosis.

Crystal deposition diseases are a group of disorders in which inflammatory damage is elicited by exposure to exogenous or endogenous crystalline molecules. Examples of exogenous activators are silica and asbestos, whose endocytosis by pulmonary macrophages results in NLRP3 inflammasome activation involving ROS and lysosome destabilization, leading in turn to silicosis and asbestosis, respectively $(96,97)$. Similarly, aberrant formation of crystals from endogenous molecules such as monosodium urate (MSU) and calcium phosphate may lead to NLRP3 inflammasome activation in macrophages. Indeed, particular accumulation of MSU has long been noted during gout, but only recently has it been shown that NLRP3-deficient mice feature defective MSU-induced neutrophil infiltration and inflammation (98). On the basis of these findings, clinical trials have been started to block IL-1 $\beta$ in gout; promising early results suggest that aberrant inflammasome activation drives inflammation in human crystal deposition disease.

The inflammatory nature of atherosclerosis is well established, but the biological agents that trigger artery wall inflammation remain largely unknown. Deposition of cholesterol crystals in arterial vessels has long been recognized as a pathognomonic feature of atherosclerosis and; moreover, recent evidence suggests that they are present at early stages of atherosclerotic lesions, coinciding with the first appearance of inflammatory cells (13). Similar to IAPP, cholesterol crystals activate the NLRP3 inflammasome through phagolysosome destabilization in mmLDL-primed mouse and human macrophages (13). LDL-receptor-deficient mice (prone to atherosclerosis) reconstituted with bone marrow deficient in NLRP3, ASC or IL- $1 \alpha / \beta$ are markedly resistant to the development of atherosclerosis, suggesting that NLRP3 inflammasome activation and $\mathrm{IL}-1$ secretion from the haematopoietic compartment are key events in the early stages of the disease (13). Thus, cholesterol crystals activate the NLRP3 inflammasome in human macrophages, indicating a novel link between cholesterol metabolism and inflammation. 


\section{Conclusions}

Currently, many thousands of papers are available in the literature confirming the cell-based mechanisms and in vivo processes that enhance the progression of atherosclerosis, which constitutes the leading cause of death in the industrialized world. Chronic inflammation of the arterial wall is a key element in the pathogenesis of atherosclerosis. Cholesterol crystals are a common, yet largely unexplored element present in atherosclerotic lesions. The cholesterol crystal-induced secretion of IL$1 \beta$ was caspase-1-dependent, suggesting the involvement of an inflammasome-mediated pathway. Silencing of the NLRP3 receptor, the crucial component in NLRP3 inflammasome, completely abolishes crystal-induced IL$1 \beta$ secretion, thus identifying NLRP3 inflammasome as the cholesterol crystal-responsive element in macrophages.

On the basis of these findings, therapeutic strategies to reduce cholesterol crystals or block the inflammasome pathway are predicted to have clinical benefits by decreasing the initiation or progression of atherosclerosis. In this context these findings also indicate novel molecular targets for the development of therapeutics to treat this disease.

\section{References:}

1. Libby P, Ridker PM, Hannsson GK. Progress and challenges in translating the biology of atherosclerosis. Nature 2011, 473: 317-24.

2. Weber $\mathrm{C}$, Noels $\mathrm{H}$. Atherosclerosis: current pathogenesis and therapeutic options. Nat Med 2011, 17: 1410-22.

3. Steinberg D. The cholesterol wars: the skeptic vs the preponderance of evidence. 1st ed. Academic Press. 2007.

4. Libby $P$. The forgotten majority: unfinished business in cardiovascular risk reduction. J. Am. Coll. Cardiol. 2005, 46: 1225-28.

5. Cannon CP, Braunwald E, McCabe CH, Rader DJ, Rouleau JL, Belder R, et al. Intensive versus moderate lipid lowering with statins after acute coronary syndromes. N. Engl. J. Med. 2004, 350: 1495-504.

6. Rye KA, Bursill CA, Lambert G, Tabet F, Barter PJ. The metabolism and anti-atherogenic properties of HDL. J. Lipid Res. 2009, 50: S195-200.

7. Vaisar T, Pennathur S, Green PS, Gharib SA, Hoofnagle AN, Cheung MC, et al. Shotgun proteomics implicates protease inhibition and complement activation in the antiinflammatory properties of HDL. J. Clin. Invest. 2007; 117: 746-56.

8. Libby P, Ridker PM. Inflammation and atherothrombosis. J. Am. Coll. Cardiol. 2006; 48: 33-46.

9. Grosser T, Fries S, FitzGerald GA. Biological basis for the cardiovascular consequences of COX-2 inhibition: therapeutic challenges and opportunities. J. Clin. Invest. 2006, 116: 4-15.
10. Weber C, Zernecke A, Libby P. The multifaceted contributions of leukocyte subsets to atherosclerosis: lessos from mouse models. Nat Rev Immunol 2008, 8: 802-15.

11. Drechsler M, Megens RT, van Zandvoort M, Weber C, Soehnlein O. Hyperlipidemia-triggered neutrophilia promotes early atherosclerosis. Circulation 2010; 122 : $1837-45$.

12. Moore $\mathrm{KJ}$, Tabas I. Macrophages in the pathogenesis of atherosclerosis. Cell 2011, 145: 341-55.

13. Duewell $P$, Kono $H$, Rayner KJ, Sirois CM, Vladimer G, Bauernfeind FG, et al. NLRP3 inflammasomes are required for atherogenesis and activated by cholesterol crystals. Nature 2010, 464: 1357-61.

14. Rajamäki K, Lappalainen J, Oörni K, Välimäki E, Matikainen S, Kovanen PT et al. Cholesterol crystals activate the NLRP3 inflammasome in human macrophages: a novel link between cholesterol metabolism and inflammation. PLoS ONE 2010, 5: e11765.

15. Majno G. The healing hand; man and wound in the ancient world. Cambridge: Harvard University Press; 1975.

16. Coggins M, Rosenzweig A. The fire within: Cardiac Inflammatory Signaling in Health and Disease. Circ Res 2012, 110: 11625.

17. Galkina E, Ley K. Immune and inflammatory mechanisms of atherosclerosis. Annu Rev Immunol 2009, 27: 165-97.

18. Bianchi ME. DAMPs, PAMPs and alarmins: all we need to know about danger. J Leukoc Biol 2001, 81: 1-5.

19. Matzinger P. Tolerance, danger, and the extended family. Annu Rev Immunol 1994; 12:991-1045.

20. Lundberg AM, Yan ZQ. Innate immune recognition receptors and damage-associated molecular patterns in plaque inflammation. Curr Opin Lipidol 2011, 22: 343 - 49.

21. Fredrikson GN, Hedblad B, Berglund G, Alm R, Ares M, Cercek $B$, et al. Identification of immune responses against aldehyde-modified peptide sequences in apoB associated with cardiovascular disease. Arterioscler Thromb Vasc Biol 2003; 23:872-8.

22. Simon DI, Zidar D. Neutrophils in atherosclerosis. Alarmin evidence of a hit and run? Circ Res 2012, 110: 1036-8.

23. Hansson GK, Hermansson A. The immune system in atherosclerosis. Nat Immunol. 2011; 12: 204-12.

24. Soehnlein O. Multiple roles for neutrophils in atherosclerosis. Circ Res. 2012; 110: 875-88.

25. Rotzius $P$, Thams $S$, Soehnlein O, Kenne E, Tseng CN, Bjo "rkstro $\mathrm{m} \mathrm{NK}$, et al. Distinct infiltration of neutrophils in lesion shoulders in ApoE/mice. Am J Pathol. 2010; 177: 493-500.

26. Zernecke A, Bot I, Djalali-Talab Y, Shagdarsuren E, Bidzhekov K, Meiler S, et al. Protective role of $\mathrm{CXC}$ receptor $4 / \mathrm{CXC}$ ligand 12 unveils the importance of neutrophils in atherosclerosis. Circ Res. 2008; 102: 209-17.

27. Borregaard N. Neutrophils, from marrow to microbes. Immunity. 2010; 33:657-70.

28. Borregaard N, Sørensen OE, Theilgaard-Mo "nch K. Neutrophil granules: a library of innate immunity proteins. Trends Immunol. 2007;28: 340-5.

29. Borregaard N, Cowland JB. Granules of the human neutrophilic polymorphonuclear leukocyte. Blood. 1997;89:3503-21.

30. Soehnlein O, Lindbom L. Phagocyte partnership during the onset and resolution of inflammation. Nat Rev Immunol. 2010; 10: 427-39.

31. Yang D, de la Rosa G, Tewary P, Oppenheim JJ. Alarmins link neutrophils and dendritic cells. Trends Immunol. 2009; 30: 531-7.

32. Soehnlein O, Zernecke A, Eriksson EE, Rothfuchs AG, Pham $\mathrm{CT}$, Herwald $\mathrm{H}$, et al. Neutrophil secretion products pave the way for inflammatory monocytes. Blood. 2008; 112 : 1461-71. 
33. van der Does AM, Beekhuizen $\mathrm{H}$, Ravensbergen $\mathrm{B}$, Vos $\mathrm{T}$, Ottenhoff TH, van Dissel JT, et al. LL-37 directs macrophage differentiation toward macrophages with a proinflammatory signature. J Immunol. 2010; 185: 1442-9.

34. Lee TD, Gonzalez ML, Kumar P, Chary-Reddy S, Grammas P, Pereira HA, CAP37, a novel inflammatory mediator: its expression in endothelial cells and localization to atherosclerotic lesions. Am J Pathol. 2002; 160:841-8.

35. Edfeldt K, Agerberth B, Rottenberg ME, Gudmundsson GH, Wang XB, Mandal K, et al. Involvement of the antimicrobial peptide LL-37 in human atherosclerosis. Arterioscler Thromb Vasc Biol. 2006; 26:1551-7.

36. Barnathan ES, Raghunath PN, Tomaszewski JE, Ganz T, Cines DB, Higazi A al-R. Immunohistochemical localization of defensin in human coronary vessels. Am J Pathol. 1997; 150: 1009-20.

37. Hemdahl AL, Gabrielsen A, Zhu C, Eriksson P, Hedin U, Kastrup $\mathrm{J}$, et al. Expression of neutrophil gelatinase-associated lipocalin in atherosclerosis and myocardial infarction. Arterioscler Thromb Vasc Biol. 2006; 26: 136-42.

38. Pereira HA, Moore P, Grammas P. CAP37, a neutrophil granulederived protein stimulates protein kinase $\mathrm{C}$ activity in endothelial cells. J Leukoc Biol. 1996; 60: 415- 22.

39. Lee TD, Gonzalez ML, Kumar P, Grammas P, Pereira HA. CAP37, a neutrophilderived inflammatory mediator, augments leukocyte adhesion to endothelial monolayers. Microvasc Res. 2003; 66: 38-48.

40. Taekema-Roelvink ME, Kooten C, Kooij SV, Heemskerk E, Daha MR. Proteinase 3 enhances endothelial monocyte chemoattractant protein-1 production and induces increased adhesion of neutrophils to endothelial cells by upregulating intercellular cell adhesion molecule-1. J Am Soc Nephrol. 2001; 12: 932-40.

41. Chaly YV, Paleolog EM, Kolesnikova TS, Tikhonov II, Petratchenko EV, Voitenok NN. Neutrophil alpha-defensin human neutrophil peptide modulates cytokine production in human monocytes and adhesion molecule expression in endothelial cells. Eur Cytokine Netw. 2000;11: 257-266.

42. Kougias $P$, Chai $H$, Lin $P H, Y a o Q$, Lumsden $A B$, Chen $C$. Neutrophil antimicrobial peptide alpha-defensin causes endothelial dysfunction in porcine coronary arteries. J Vasc Surg. 2006; 43: 357-63.

43. Zhang J, Alcaide P, Liu L, Sun J, He A, Luscinskas FW, et al. Regulation of endothelial cell adhesion molecule expression by mast cells, macrophages, and neutrophils. PLoS One. 2011; : e14525.

44. van Leeuwen M, Gijbels MJ, Duijvestijn A, Smook M, van de Gaar $\mathrm{MJ}$, Heeringa $\mathrm{P}$, et al. Accumulation of myeloperoxidasepositive neutrophils in atherosclerotic lesions in LDLR-/mice. Arterioscler Thromb Vasc Biol. 2008; 28: 84-89.

45. Baetta R, Corsini A. Role of polymorphonuclear neutrophils in atherosclerosis: current state and future perspectives. Atherosclerosis. 2010; 210:1-13.

46. Podrez EA, Schmitt D, Hoff HF, Hazen SL. Myeloperoxidasegenerated reactive nitrogen species convert LDL into an atherogenic form in vitro. J Clin Invest. 1999;103:1547-60.

47. Kai $H$, Ikeda $H$, Yasukawa $H$, Kai M, Seki $Y$, Kuwahara $\mathrm{F}$, et al. Peripheral blood concentrations of matrix metalloproteases-2 and -9 are elevated in patients with acute coronary syndromes. J Am Coll Cardiol. 1998;32:368-72.

48. Phillipson M, Kubes $P$. The neutrophil in vascular inflammation. Nat Med 2011, 11: 1381-90.

49. Swirski FK, Weissleder R, Pittet MJ. Heterogeneous in vivo behavior of monocyte subsets in atherosclerosis. Arterioscler Thromb Vasc Biol 2009, 29: 1424-32.

50. Ley K, Miller YI, Hedrick CC. Mpnocyte and macrophage dynamics during atherogenesis. Arterioscler Thromb Vasc Biol 2011, 31: 1506-16.
51. Glass CK, Witztum JL. Atherosclerosis. The road ahead. Cell 2001, 104: 503-16.

52. Mestas J, Ley K. Monocyte-endothelial cell interactions in the development of atherosclerosis. Trends Cardiovasc. Med. 2008, 18: 228-32.

53. Johnson JL, Newby AC. Macrophage heterogeneity in atherosclerotic plaques. Curr. Opin. Lipidol. 2009, 20: 3708.

54. Paulson KE, Zhu SN, Chen M, Nurmohamed S, Jongstra-Bilen $\mathrm{J}$, Cybulsky MI. Resident intimal dendritic cells accumulate lipid and contribute to the initiation of atherosclerosis. Circ. Res. 2010; 106: 383-90.

55. Gordon S. Alternative activation of macrophages. Nat Rev Immunol. 2003; 3:23-35.

56. Mantovani A, Sozzani S, Locati M, Allavena P, Sica A. Macrophage polarization: tumor-associated macrophages as a paradigm for polarized M2 mononuclear phagocytes. Trends Immunol. 2002;23: 549-55.

57. Mosser DM, Edwards JP. Exploring the full spectrum of macrophage activation. Nat Rev Immunol. 2008; 8: 958-69.

58. Pollard JW. Trophic macrophages in development and disease. Nat Rev Immunol. 2009; 9: 259-70.

59. Martinez FO, Sica A, Mantovani A, Locati M. Macrophage activation and polarization. Front Biosci. 2008;13: 453-61.

60. Auffray C, Sieweke MH, Geissmann F. Blood monocytes: development, heterogeneity, and relationship with dendritic cells. Annu Rev Immunol. 200927: 669-92.

61. Mantovani A, Garlanda C, Locati M. Macrophage diversity and polarization in atherosclerosis. A question balance. Arterioscler Thromb vasc Biol 2009, 29: 1419-23.

62. Kunjathoor VV, Febbraio M, Podrez EA, Moore KJ, Andersson L, Koehn S, et al. Scavenger receptors class A-I/II and CD36 are the principal receptors responsible for the uptake of modified low density lipoprotein leading to lipid loading in macrophages. J. Biol. Chem. 2002; 277: 49982-8.

63. Moore, K.J., Kunjathoor, V.V., Koehn, S.L., Manning, J.J., Tseng, A.A., Silver, J.M, et al. Loss of receptor-mediated lipid uptake via scavenger receptor $\mathrm{A}$ or CD36 pathways does not ameliorate atherosclerosis in hyperlipidemic mice. J. Clin. Invest. 12005; 15: 2192-201.

64. Manning-Tobin JJ, Moore KJ, Seimon TA, Bell SA, Sharuk M, Alvarez-Leite $\mathrm{JI}$, et al. Loss of SR-A and CD36 activity reduces atherosclerotic lesion complexity without abrogating foam cell formation in hyperlipidemic mice. Arterioscler. Thromb. Vasc. Biol. 2009, 29: 19-26.

65. Tabas I, Li Y, Brocia RW, Xu SW, Swenson TL, Williams KJ. Lipoprotein lipase and sphingomyelinase synergistically enhance the association of atherogenic lipoproteins with smooth muscle cells and extracellular matrix. A possible mechanism for low density lipoprotein and lipoprotein(a) retention and macrophage foam cell formation. J. Biol. Chem. 1993; 268: 20419-32.

66. Kruth HS, Jones NL, Huang W, Zhao B, Ishii I, Chang J, et al. Macropinocytosis is the endocytic pathway that mediates macrophage foam cell formation with native low density lipoprotein. J. Biol. Chem. 2005; 280: 2352-60.

67. Maxfield FR, Tabas, I. Role of cholesterol and lipid organization in disease. Nature 2005, 438: 612-21.

68. Tarr PT, Edwards PA. ABCG1 and ABCG4 are coexpressed in neurons and astrocytes of the CNS and regulate cholesterol homeostasis through SREBP-2. J. Lipid Res. 2008, 49: 169-82.

69. Tall AR, Yvan-Charvet L, Terasaka N, Pagler T, Wang N. HDL, $A B C$ transporters, and cholesterol efflux: implications for the treatment of atherosclerosis. Cell Metab 2008, 7: 36575 . 
70. Rothblat GH, Philips MC. High - density lipoprotein heterogeneity and function in reverse cholesterol transport. Curr Opin LIpidol 2010, 21: 229-38.

71. Libby P. Inflammation in atherosclerosis. Nature. 2002; 420 : 868-74.

72. Galkina E, Ley K. Leukocyte influx in atherosclerosis. Curr Drug Targets. 2007; 8: 1239-48.

73. Shibata N, Glass GK. Regulation of macrophage function in inflammation and atherosclerosis. J Lipid Res 2009, 50 : S277-81.

74. Adamson S, Leitinger N. Phenotypic modulation of macrophages in response to plaque lipids. Curr Opin Lipidol 2011, 22: 335 $-42$.

75. Waldo SW, Li Y, Buono C, Zhao B, Billings EM, Chang J, et al. Heterogeneity of human macrophages in culture and in atherosclerotic plaques. Am J Pathol 2008; 172:1112-26.

76. Bouhlel MA, Derudas B, Rigamonti E, Dièvart R, Brozek J, Haulon $\mathrm{S}$, et al. PPARgamma activation primes human monocytes into alternative M2 macrophages with antiinflammatory properties. Cell Metab 2007; 6:137-43.

77. Kadl A, Meher AK, Sharma PR, Lee MY, Doran AC, Johnstone $\mathrm{SR}, \mathrm{R}$, et al. Identification of a novel macrophage phenotype that develops in response to atherogenic phospholipids via Nrf2. Circ Res 2010; 107:737-46.

78. Rath E, Haller D. Inflammation and cellular stress: a mechanistic link between immune-mediated and metabolically driven pathologies. Eur J Nutr. 2011;50:219-33.

79. Zhang K. Integration of ER stress, oxidative stress and the inflammatory response in health and disease. Int J Clin Exp Med. 2010;3:33-40.

80. Kitamura M. Control of NF-kB and inflammation by the unfolded protein response. Int Rev Immunol. 2011;30:4-15.

81. Hotamisligil GS. Endoplasmic reticulum stress and the inflammatory basis of metabolic disease. Cell. 2010;140:900-27.

82. Zhang K, Shen X, Wu J, Sakaki K, Saunders T, Rutkowski DT, et al. Endoplasmic reticulum stress activates cleavage of CREBH to induce a systemic inflammatory response. Cell. 2006;124: 587-99.

83. Zhang K, Kaufman RJ. From endoplasmic-reticulum stress to the inflammatory response. Nature. 2008; 454: 455-62.

84. Gotoh T, Endo M, Oike Y. Endoplasmic reticulum stress-related inflammation and cardiovascular diseases. Int J Inflam. 2011, 2011: 259462.
85. Tabas I. The Role of Endoplasmic Reticulum Stress in the Progression of Atherosclerosis. Circ Res 2010, 107: 83950.

86. Martinon F, Mayor A, Tschopp J. The inflammasomes: guardians of the body. Annu Rev Immunol 2009, 27: 229 - 65.

87. Matzinger P. 2002. The danger model: a renewed sense of self. Science 296:301-5.

88. Seong SY, Matzinger P. Hydrophobicity: an ancient damageassociated molecular pattern that initiates innate immune responses. Nat. Rev. Immunol.2004, 4: 469-78

89. Ishii KJ, Suzuki K, Coban C, Takeshita F, Itoh Y, Matoba H, et al. 2001. Genomic DNA released by dying cells induces the maturation of APCs. J. Immunol. 167:2602-7

90. Martinon F, Pe trilli V, Mayor A, Tardivel A, Tschopp J. 2006. Gout-associated uric acid crystals activate the NALP3 inflammasome. Nature 440:237-41

91. Schroder K, Tschopp J. The inflammasomes. Cell 2010, 140: 821-32.

92. Davis BK, Wen $H$, Ting JP. The inflammasome NLRs in immunity, inflammation, and associated diseases. Annu. Rev. Immunol. 2011, 29, 707-35.

93. Dinarello CA. IL-1: discoveries, controversies and future directions. Eur. J. Immunol. 2010, 40: 599-606.

94. Cerretti DP, Kozlosky CJ, Mosley B, Nelson N, van Ness K, Greenstreet TA, et al. Molecular cloning of the interleukin$1 \beta$ converting enzyme. Science 1991, 256: 97-100.

95. Keller M, Rüegg A, Werner S, Beer HD. Active caspase-1 is a regulator of unconventional protein secretion. Cell 2008, 132: 818-31.

96. Hornung V, Bauernfeind F, Halle A, Samstad EO, Kono H, Rock $\mathrm{KL}$, et al. Silica crystals and aluminum salts activate the NALP3 inflammasome through phagosomal destabilization. Nature Immunol. 2008, 9: 847-56.

97. Cassel SL, Eisenbarth SC, lyer SS, Sadler JJ, Colegio OR, Tephly LA, et al. The Nalp3 inflammasome is essential for the development of silicosis. Proc. Natl Acad. Sci. USA 2008, 105: 9035-40.

98. Martinon F, Pétrilli V, Mayor A, Tardivel A, Tschopp J. Goutassociated uric acid crystals activate the NALP3 inflammasome. Nature 2006, 440: 237-41. 